but as the place where Siva devised how to destroy Tripura and where he fixed (or stayed) his arrow. ${ }^{1}$ We see then that, when these māhätmyas were composed, Māhiṣmatī (Mandhāta) had been forgotten locally and Maheśvara claimed sanctity only on the ground of a brief legendary connexion with Siva. We may well conjecture, therefore, that the brahmans of Maheswar, finding afterwards that the ancient glory of Māhișmati was not located at or utilized by any place on the Narbada, claimed it for their town on the strength of a similarity in the two names, and in the absence of any counter-claimant succeeded in appropriating it.

Mahișa-maṇdala appears to be a Buddhist appellation. It does not (as far as I know) occur in the Epics or Purānas, nor is it mentioned in Monier-Williams' or Böhtlingk and Roth's Dictionary.

F. E. Pargiter.

\title{
The Genitive-Accusative in Indian Vernaculars
}

Mr. Lesny's note (pp. 481-4 of the Journal for April) on the use of the genitive for the accusative in Marathi will interest students of other vernaculars. His explanation is that the genitive is used in the case of living beings to avoid ambiguity, where there is no special termination to distinguish nominative from accusative. In Bengali the ambiguity only arises in the case of inanimate things, since living things have a dative-accusative termination in -ke. In using the double accusative, this ambiguity is avoided by boldly giving the accusatival termination to the (inanimate) direct object. For instance, "tini rātri-ke din, din-ke rātri karite pāren" (he can make night day, and day night).

1 Matsya, Ānandāśrama ed., 188, 1-2 and 82 (Calc. ed., 187). Padma, i, 15, I-2 and 71 . These two accounts are very closely alike. The word sthina is noteworthy and significant. It could hardly be applied to an ancient city, but rather suggests a new place. 
But (and this is my excuse for writing) the genitive is often used in poetry and in common talk for the dative or accusative of plural nouns signifying rational beings. Thus, it is permissible to say "ai bālak-der dāo" (give to those boys), or "yāhārā e kāj kariyāche, tāhāder māra" (chastise those who have done these things).

In the singular number, an alternative to the dativeaccusative termination in $-k e$ is used. This only differs from the genitive in form in having an $-e$ added to it. Thus, in familiar talk, you may say "āmā-re dāo" for "āmā-ke dāo" (give to me), or "tini âmă-re dekhilen" (he saw me), for " tini āmā-ke dekhilen".

There can be here no question of avoiding ambiguity. May I make the purely tentative suggestion that the original termination for genitive, dative, and accusative was that which is now reserved for the genitive, and that the -ke, which now marks dative and accusative, was borrowed? In Kachäri (a Tibeto-Burmese language which was once the native tongue of many who now speak Bengali or Assamese) the genitive in -ni occurs in cognate dialects which have not come into contact with Indo-European languages, whereas the Kachāri dativeaccusative in -ko or -kho was probably borrowed.

Generally, the case terminations are used by Bengalis in a way that seems somewhat loose to the European, a fact that adds to the idiomatic flexibility and picturesqueness of their language. This too may be due to borrowing.

$$
\text { J. D. A. }
$$

\section{"Genitive-Accusative" Construction in Marathi}

In support of Professor Thomson's theory as regards the origin of the genitive construction, Dr. Lesny' has quoted a few sentences from Marăthi reading-books and shown that the construction in question has been "the outcome of nothing else than a desire to avoid ambiguity". 